\title{
Stockpile Sensor Increases the Availability of Yard Equipments-Ports
}

\author{
G. Vara Prasad Babu, M. Pramila Devi
}

\begin{abstract}
The purpose of the study is to assess the importance of stock pile sensor plays a pivotal role in the availability of yard equipment's wiz reclaimers, stackers, stacker cum reclaimers. By increasing the availability of the equipment we can reduce the turnaround time of the vessel by which the customer satisfaction can be achieved optimistically. The stock pile sensor been installed for irregular contact of boom while reclaiming/ stacking, and to prevent damage of bucket wheel teeth from worn out. The stock pile sensor and inter lock system and chute block sensors ensures the reduction of over tons per hour issues arising from sudden stoppage of conveyors along the operational circuit under operations, chutes and tripper car discharge chutes over choked with cargo related issues, considering the parameters of man power, and time factors can be saved and can be used for other maintenance purposes and to get back the circuit into operational effectiveness increasing the availability of the yard equipment's.
\end{abstract}

keywords: Gangavaram port limited, stock pile sensor, tons per hour, bucket wheel.

\section{INTRODUCTION}

\section{Stockpile}

The dumping of cargo in yard, May sometime be uneven in storage forms, sometimes in increased conical configurations and sometimes un-stratified ways, due to rain and windy conditions the stockpile dimensions may get effected. Hence the study of stockpile before reclamation is important for safety of the equipment and human resource.

Stockpile layouts and stacking methods

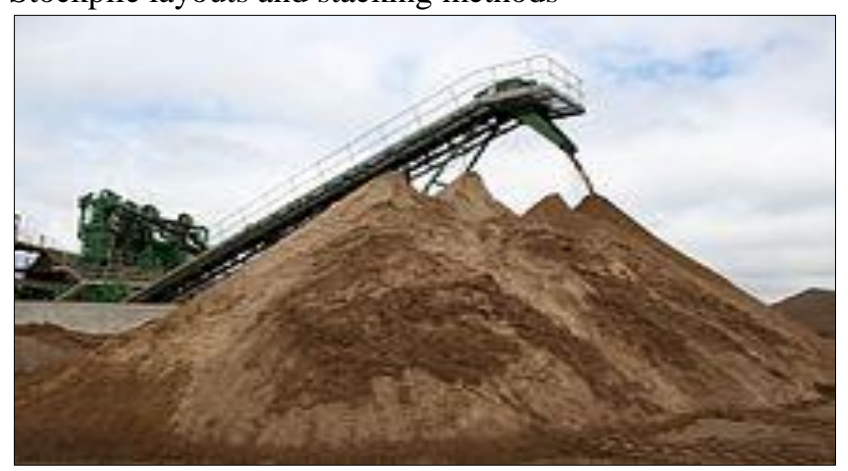

Fig. 1: stacking positions in yard

Revised Manuscript Received on April 25, 2020.

* Corresponding Author

G. Vara Prasad Babu*, scholar, Department of Mechanical Engineering, Andhra University, Visakhapatnam, Andhra Pradesh, India.Email: vara2637@gmail.com

Prof. M. Pramila Devi, Principal, women's college of engineering, Andhra university, Visakhapatnam, Andhra Pradesh, India, Email: pramiladevi_m@yahoo.co.in

(C) The Authors. Published by Blue Eyes Intelligence Engineering and Sciences Publication (BEIESP). This is an open access article under the CC BY-NC-ND license (http://creativecommons.org/licenses/by-nc$\underline{\mathrm{nd} / 4.0 /)}$

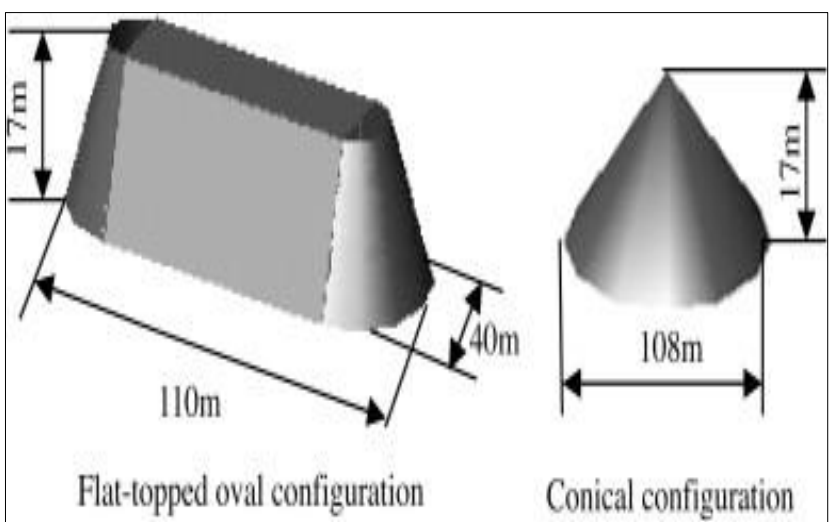

Fig. 2: stock pile layouts

\section{Availability}

The availability of stock piles in the yard is more important for smooth undergoing of operations, because -different kind of grades of cargo e.g. coal be available but in the recognizing what kind of grade should be reclaimed or stacked as per operations requirement is necessary.

-stock pile reorganization and having an accurate information regarding how much quantity is available in yard plays a vital role in operations.

-dozing of cargo for requirements is necessary due to sometimes due to weather conditions the cargo becomes wet and we are unable to reclaim the cargo for desired operational requirements.

-storage of cargo is necessary in stocks when the customer requirements of collecting the cargo is delayed by months' time often, the cargo should be properly secured from atmospheric conditions, due to yards some times are often not provided with sheds for storage.

-stock piles reach-ability for proper reclamation space constraints should be optimally taken in to considerations as per operations requirement from day to day basis.

\section{Stacker cum Reclaimer}

Stacker cum reclaimer can stack and reclaim the cargo by changing the mode in the boom centre discharge chute, by which stacking and reclaiming modes can be used based on the operational requirements in the yard.

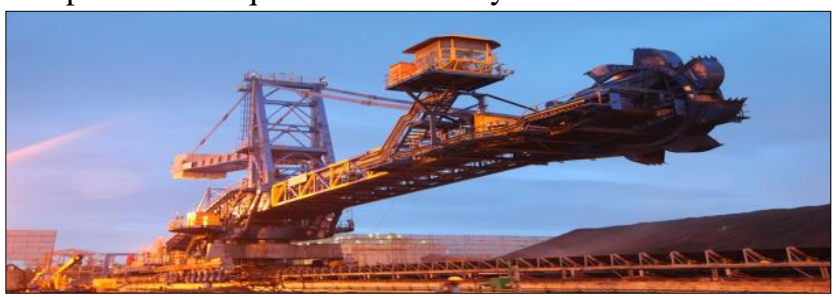

Fig.3: Stacker cum reclaimer

Published By:

Blue Eyes Intelligence Engineering

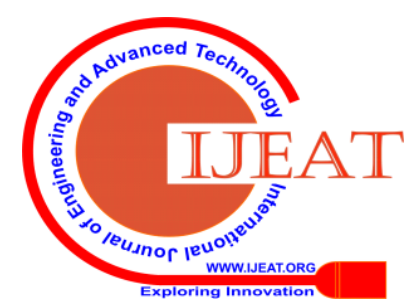




\section{METHODOLOGY}

\section{Development of Stockpile Level Soft Sensor}

A typical stockpile consists of a feeding conveyor, a cone space to pile material and discharging hopper and conveyor feeder at the bottom.

A stockpile level can be presented by the percentage of fullness in two formats, namelyby percentage of mass and by percentage of the level. The mass percentage is defined as theactual mass over the total ore mass of a full stockpile (Mass \%). The level percentage is theactual height of ore over the maximum height of a full stockpile (Level \%). The definitionfor both Mass\% and Level\% can be expressed in the following equations:

Mass-full \% = (Ot)/ (Ot-FS) 100 (1)

Level-full \% $=(\mathrm{Ol}) /(\mathrm{Ol}-\mathrm{FS}) \cdot 100(2)$

Where:

Ot -actual ore/coal tonnage in stockpile, ton,

Ot-FS -ore/coal tonnage of full stockpile, ton,

Ol - actual ore/coal level in stockpile, meter,

Ol-FS -ore/coal level of full stockpile, meter.

\section{Stockpile Level Measurement}

Many different technologies are available today to measure stockpile levels, and it is important to know that no one technology is suitable for all applications [2]. Therefore it is imperative to understand fully the required process needs and the capabilities of various level measurement technologies, before deciding on a level measurement solution for a solid stockpile.

To increase the availability of equipment, though the

-tripping devices

-Interlocking devices

-lock out systems

-sirens

-and other equipment safety switches

With all these safety devices to run the stream optimistically, stock pile sensor implementation will increase the availability for operations requirement.

Man power

Man power resource utilisation is very important factor for any organization with respect to their time and allocation of jobs, with these safety devices prompt implementations hazards and accidents can be reduced and productivity rate of organization increases.

\section{Turnaround time}

The vessel targets of unloading can be achieved with rate of capacity with which the conveyors are meant to be can achieved, there by the required tons per hour cargo can be unloaded or loaded to require destinations with in the time constraint.

\section{Practical Orientation:}

Stock pile sensor implemented in Gangavaram Port Limited (GPL) by which boom fouling with yard stock piles reduced and choking of tripper car discharge chutes and transfer towers reduced drastically. The man power used for clearing the cargo in the chutes is reduced and optimal saving of time.

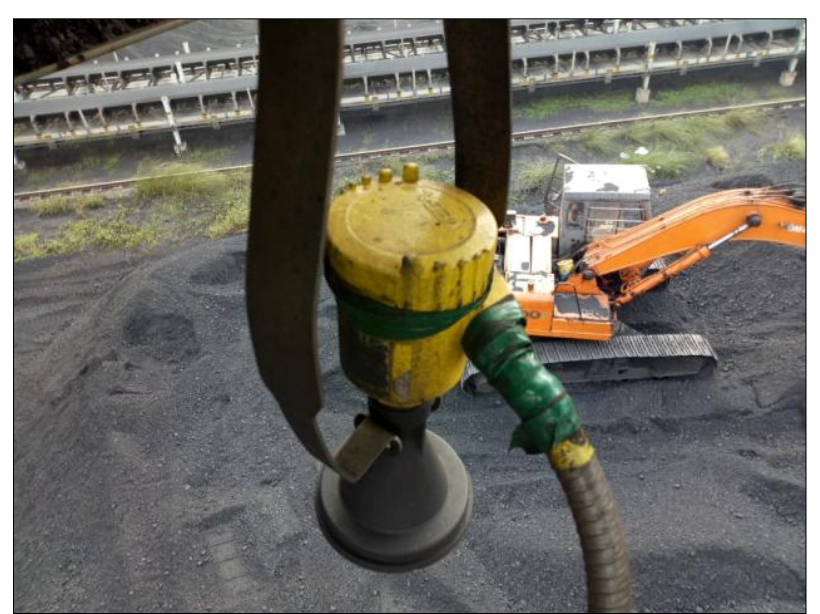

Fig. 4: stock pile sensor in GPL

\section{RESULTS AND DISCUSSIONS}

Installing and maintaining the stock pile sensor yields optimal reducing choking of chutes and the stock pile sensor ensures irregular contact of boom while reclaiming/ stacking, and to prevent damage of bucket wheel teeth from worn out. The stock pile sensor and inter lock system and chute block sensors ensures the reduction of over tons per hour issue, chutes and tripper car discharge chutes over choked with cargo related issues, increasing the availability of the equipment.

\section{CONCLUSION}

The stock pile sensor reduces the minimum down time of failure rate by increasing the availability of the equipment without any cargo jam issues in chutes there by increasing the productivity of the cargo discharged as per operations requirements. Various technologies are available to provide the level measurements for a stockpile, including Yo-Yo or weight and cable, laser and radar. It is important for users to understand the required measurement task and the process need before deciding on a level measurement solution. Safety and reliability, and accuracy remain crucial, while at the same time, the specific measurement equipment needs to be chosen with the consideration of easy to install and operate at a low cost of ownership. A software based level measurement, level soft sensor, proves an attractive alternative.

\section{REFERENCES}

1. Gangavaram Port limited, Vizag.

2. Samancor, http://www.minig-technilogy.com/projects/samancor/, May 2011.

3. Little T.: Level Measurement Trends in the Solid Industry,http://knol.google.com/k/level-measurement-trends-in-thesolids-industry.

4. Little T.: Non-Contact Level Measurement in "Open Air" Applications, http://knol.google.com/k/non-contact-levelmeasurement-in-open-air- applications.

5. Stockpile, Stacker and Reclaimer, http://en.wikipedia.org/wiki/Stacker.

6. Lethem D.: Online Stockpile Analysis, World Cement, January 2008, pp. 27-30 or athttp://www.worldcement.com/.

$\begin{array}{llll}\text { 7. Geoscan, 5175R0 Geoscan-C UGG.doc, } & \end{array}$ http://www.scantech.com.au, 10 Oct 2010.

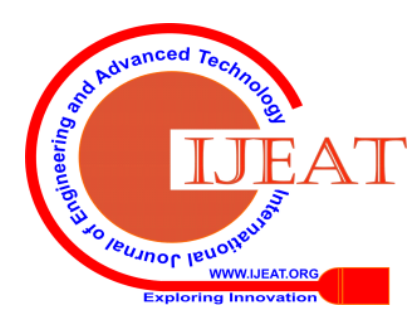


8. Sharma Shilpa (2013), "safety features for failures in stacker cum reclaimers"vol2, issue 9,(IJSR) Engineering Science and Application Design for Belt Conveyors by Mr. I.G. Mulani.

9. Stacker and reclaimer systems for cement plants by FLSmidth (www.flsmidth.com) Performances in Stockyard Technologies by SCHADE AUMUND Group (www.schadelagertechnik.com)

10. Solutions in Bulk Material Handling by Metso Minerals (India) Pvt Ltd, India

11. O \& M Manual for a boom type bucket wheel stacker cum reclaimer by TRF Ltd, India, A

12. Tata Enterprise (www.trf.co.in)

13. AGH Journal of Mining and Geoengineering • vol. 36 • No. 4 • 2012

\section{AUTHOR PROFILE:}

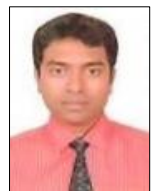

G. Vara Prasad Babu, he is working as Deputy Manager at Gangavaram Port Limited, Visakhapatnam and Currently pursuing Ph.D. in the Department of Mechanical Engineering, Andhra University, Visakhapatnam, Andhra Pradesh, India. He has Received Master of Engineering (Industrial Engineering) and MBA (HRM) In Andhra University, Visakhapatnam, Andhra Pradesh, India.

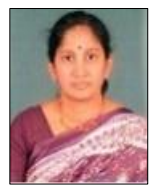

Prof. M. Pramila Devi received Ph.D. in the Department of Mechanical Engineering, Andhra University, Visakhapatnam, Andhra Pradesh, India. She is working as a professor, Department of Mechanical Engineering, Andhra University, Visakhapatnam, Andhra Pradesh, India.

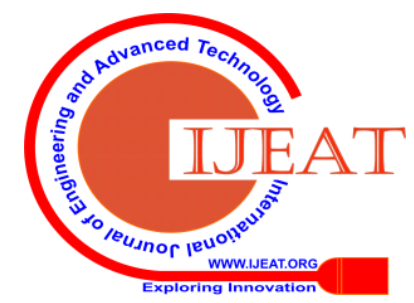

